\title{
Persuasive Communication in Pluralistic Communities in The Perspective of Islam
}

\author{
M. Nasor ${ }^{1}$ \\ \{nasor@radenintan.ac.id ${ }^{1}$ \} \\ Universitas Islam Negeri Raden Intan, Bandar Lampung, Lampung, Indonesia ${ }^{1}$
}

\begin{abstract}
A pluralistic community is a community that consists of various groups, races, ethnicities, nations, and others. Its existence must be guided so that the community could possess the loving and kind characters, opposing evil, and avoiding violence as stated in the Islamic teachings. Universal Islamic values regulate relationships based on aspects of mutual respect, non-coercion, principles of justice, humanity, togetherness, and brotherhood. Islam as a social religion strongly supports the existence of efforts to establish a strong relationship between human dignity and worthiness. For this reason, it seems that persuasive communication is needed which can reach the psychological aspects of various sections of the community. This method will be easier to bring effective results through the commitment of each group regarding faith and humanity with the limits of their rights and obligations. That situation can foster motivation and confidence to achieve unity and benefit of the community guided by religious and humanitarian values.
\end{abstract}

Keywords: Islam, Persuasive Communication, Pluralistic Community.

\section{Introduction}

A pluralistic community is a community that consists of various ethnicities, cultures, religions, and customs that can live together. Maulavi Muhammad Ali explains that the existence of the Medina community was a community consisting of Muslims and Jews as well as others as a nation that lived mixed and mingled with others. ${ }^{1}$ The diversity of the people of Medina can also be seen in the diversity of sexes, ethnicities, races, and nations. The Medina community consisted of Muhajirins, Ansars, non-believers, pagan tribes, and Jews. ${ }^{2}$

Pluralistic communities live in a heterogeneous and complex life which indicates that they consist of various groups. Each of these groups has a variety of tribes that are supposed to live in harmony and unity, but in different views, it causes people to be diverse and different. The human backgrounds are varied due to a binding different set of ideologies, as explained Surah Yunus verse 19:

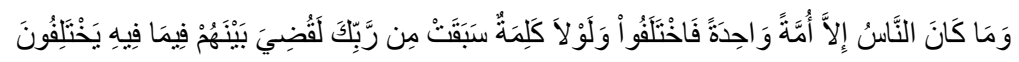

\footnotetext{
${ }^{1}$ Maulavi Muhammad Ali, Muhammad The Prophet (Lahore: Iradahi al-Adabiyati, 1950), 121.

${ }^{2}$ Zainal Abidin Ahmad, Piagam Nabi Muhammad SAW Konstitusi Tertulis Pertama Di Dunia (Jakarta: Bulan Bintang, 1973), 93.
} 
Meaning: Mankind were but a single [religious] community; then they differed. And were it not for a prior decree of your Lord, decision would have been made between them concerning that about which they differ. ${ }^{3}$

The verse above, according to Abdullah, shows that at the beginning, the people lived in harmony, united in one religion, and came from one community. But then they split into several groups. As a result, a variety of beliefs that cause division arose. There are those who follow the teaching of Allah and there are those who deny it. ${ }^{4}$ The reality of human life in the world is described as a group of people who truly obey the teachings of religion and there are a group of people who defied it. In other words, there is indeed a group of people who declare themselves to be Muslims and there are groups who claim to be the followers of other religions.

Medina community whose life was very pluralistic is the essence of a prone to conflict community if it was left without any guidance towards harmonious life and mutually respectful to one another. Sumardi relates that the plural community of Medina led by the prophet Muhammad SAW was given the freedom to implement a system of values for its citizens. ${ }^{5}$ This condition is the obligation of the preachers to foster and develop it towards a better and conducive direction. The prophet Muhammad (PBUH) after moving to Medina had carried out a lot of teachings focused on the development of the social system of community in various elements of life. Mahmud described the progress of the prophet Muhammad in fostering the community brought positive aspects to the order of social life so that he was known as a reformer for the correct system of social order. ${ }^{6}$

The success in supporting the community is inseparable from his expertise in implementing persuasive communication to build more advanced and civilized communities in the frame of unity. The community group guided by the prophet was a group of Muslims who applied the amar ma'ruf nahi munkar (commanding the good and forbidding the evil) and always paid attention to the values of virtue. Those values certainly brought them to a high level of solidarity and loyalty to jihad in defending the truth. Such a personality is needed to lead to the welfare of the community in the frame of unity. It was a civilized community with people who can live together in togetherness. ${ }^{7}$ Another characteristic of a civilized community is a community that is submissive and obedient to the law and regulation. ${ }^{8}$

Such a characteristic of the community is the basic idea in fostering a pluralistic community with a loving, kindness, and commanding the good and forbidding the evil characteristics. All of that is impossible to achieve properly without the character of the prophet Muhammad who put forward persuasive communication. He has a gentle character that can touch aspects of human psychology. Arnold explains that the policy developed by the prophet Muhammad in fostering a pluralistic community through persuasive communication

\footnotetext{
${ }^{3}$ Departemen Agama, Al-Qura'an Dan Terjemahnya (Jakarta: Yayasan Penterjemah/Penafsir Al-Qur'an, 1971), 308.

${ }^{4}$ Abdullah al-Ahsan, Ummah or Nation?, Identity Crisis in Contemporary Muslim Society (The Islamic Fondation, 1992), 12.

${ }^{5}$ Dedy Sumardi, "Islam Pluralisme Hukum Dan Refleksi Masyarakat Homogen," Jurnal Asy-Syir'ah 50, no. 2 (2016): 483.

${ }^{6}$ Sayyid Mahmud al-Nasir, Islam Konsepsi Dan Sejarahnya (Bandung: PT. Remaja Karya Rosda Karya, 1994), 119.

${ }^{7}$ Yusuf Qardhawi, Al-Sunnah Mashdaran Li al-Ma'rifah Wa al-Hadharah (Cairo: Dar al-Syuruq, 1977), 243.

${ }^{8}$ Ahmad Baso, Civil Society Versus Masyarakat Madani (Bandung: Pustaka Hidayah, 1999), 21.
} 
was kind and gentle. ${ }^{9}$ The formulation of the problem is: how is the application of persuasive communication in a pluralistic community from an Islamic perspective?

\section{Research Methodology}

This type of research is literary research. This type of research is carried out by reading and studying books by quoting from various theories and opinions that have a relationship with the focused problems. The writer examined studies, information, and data related to persuasive communication in Islam used to foster a pluralistic community.

The data sources of this study are primary and secondary data. The primary data sources are books related to Islamic persuasive communication in pluralistic societies. The books are Sirah Nabawiyah by Ibn Hisham, al-Sunnah Mashdaran li al-Ma'rifah wa al-Hadharah by Yusuf Qardhawi, Classical Islam by GE Von Grunebaum, The Preaching of Islam by Thomas W. Arnold, and the Social Contract and Islamic State by Muhammad Isya Ayash.

The secondary data sources are data based on other literature related to persuasive Islamic communication in pluralistic societies namely: Persuasion, Reception, and Responsibility by Charles U. Larson, Ummah or Nation? Identity Crisis in Contemporary Muslim Community by Abdullah al-Ahsan, and Communication Intercultural: A Guide to Communicating with People Different in Culture by Dedy Mulyana,

To analyze the data through a historical approach, the past events related to persuasive Islamic communication in fostering a pluralistic life community were studied. The discourse analysis was also used, namely, a research approach to see the development of discourse which includes speeches and all kinds of texts in a broad sense.

\section{Research Results and Discussion}

\subsection{The urgency of Persuasive Communication in Fostering Pluralistic Communities}

Persuasive communication as the main variable has an important position for the successful implementation of community development. Through this communication, one can channel and explain policy rules by paying attention to one's psychological aspects. The goal is that the community as an object of guidance can understand clearly without any misunderstanding. This communication can be easier to understand so that the community will also be easier to apply it in their lives. It is necessary for the first master and understands the various methods and principles of persuasive communication. This is so that the implementation of communication can be carried out in achieving high effectiveness and satisfaction. The persuasive communication techniques must be considered by the persuader (people who do persuasion). Techniques in the persuasion process seem to be able to raise opportunities for people to be persuaded ethically and rationally. This is very important for the recipients to know the hidden agenda of persuaders to be ready to reject it. The recipients

\footnotetext{
${ }^{9}$ Thomas W. Arnold, The Preaching of Islam (Jakarta: Wijaya, 1985), 4.
} 
should be critical of the evidence presented to them. It is important to gather information from all parties in debate and will only hold the final decision if all data has been obtained. ${ }^{10}$

In persuasive communication techniques, the persuadee is not just conveying information but wants a voluntary awareness to make changes in attitudes and behavior. Such communication technique is called persuasive communication. The term persuasive comes from the English word, namely persuasion and the word comes from the Latin word, persuasio, which means inviting and convincing. What is meant by persuasive is an action based on psychological aspects that can arouse individual awareness. Thus, it can be said that persuasive communication is the delivery of messages to others that aim to change attitudes and behaviors by focusing on human traits so that these changes can go according to the awareness and willingness of individuals. ${ }^{11}$

There are several techniques for managing messages used in persuasive communication, namely:

a. Association techniques, the messages are delivered together with interesting objects.

b. Integration Technique, the communicator integrates themselves with the subject communicatively.

c. The reward technique, to influence others by promising hope.

d. The order technique, an effort to arrange the messages to be pleased to hear.

e. The Red-herring technique, the art of winning with arguments to weaken opponents. ${ }^{12}$

Various persuasive techniques above are very important to be observed in the delivery of the messages. The audience often receives complex and diverse messages from various directions. Thus, the messages delivered are not determined or focused by just one element but will be related to other elements. The better the synergy of the element, the easier to convey the message and it will even be easier to absorb the meaning contained in the message delivered. Regarding the synergy of togetherness in persuasive communication, there will be no dependence on one element in communicating. Thus, there will be no more assumption that successful communication is not only located or dependent on the communicator, the communicant, the message, and the media. The integrated involvement of the existing elements will complement each other in the process of persuading someone. So that the idea or content of the message can be perceived properly by the recipient by involving all elements so that the person feels actively involved and participates in the persuasion process. Through the direct and active involvement of all elements, it will be easier to persuade those who ultimately agree to the contents of the message sincerely and not because it is forced by any party.

\subsection{The Application of Persuasive Communication in the Pluralistic Community in Islamic Perspective}

Pluralism is a historical reality that has a solid foundation, undeniable, and has noble values for the welfare of the community. The values of pluralism explained by the religious figures through persuasive communication to foster the community in the frame of unity in an Islamic perspective can be traced as follows:

10 Charles U. Larson, Persuasion, Reception, and Responsibility (USA: Wadsworth Publishing Company, 1986), 9.

${ }^{11}$ M. Nasor, Kontribusi Komunikasi Dalam Perencanaan Dan Kebijakan Sosial (Bandar Lampung: Universitas Lampung Press, 2012), 13.

${ }^{12}$ Nasor, 14 


\section{a. The community that Upholds Faith}

In pluralistic life, besides holding firmly to aqeedah (creed) and faith, it is also allowed to engage in human relations. Life in the common ground of aqeedah must be used as a basis for a relationship outside of the matter of religion since it is permissible to interact about the problems of social life that do not distinguish sex, ethnicity, religion, customs, nation and many other. Ahmad states that plurality is a reality that has become the will of God. Nations and tribes are created so that they should know and appreciate each other. ${ }^{13}$ The prophet Muhammad built the people of Medina which consisted of various groups; they are the Muslim community, Mushrikin community (paganism), the Jewish community, and the Christian community. ${ }^{14}$ In addition, the people of Medina were consisted of several groups, namely: Muslims that consisted of Jews and Ansar, Auws and Khazzraj people who had just converted to Islam (even though some of them opposed Muslims), people the Auws and Khazzraj who were still adhered to the pagan belief and did not become Muslims for long duration, Jews consisting of the Banu Nadzir, Banu Qoinuqa, and Banu Quraidhah tribes. ${ }^{15}$ The Medina Charter regulates the problem of tolerance beginning with the sentence in the name of God, the benevolent, and beneficence. Muhammad as the messenger of God with the people of Quraysh and Yathrib in Medina as the followers and the people who followed him joined together and struggled with them. ${ }^{16}$

b. The community that Upholds the Law

Life in diversity can run well when people realize that they cling to the law for justice. The fair dimension of law enforcement is a prerequisite for fostering the community by laying the foundations of order that covers all components of the community. Fairness or justice has an important meaning for the community which is to strengthen the bond and eliminate tribal fanaticism between groups. Justice is a parallel action in the citizens' conformity to their rights and obligations. According to Candra, paying attention to the principles of human rights (obligations) is not only became the most important aspect in a country's legal system that must be stated in the constitution but also demanded overall recognition at the level of its implementation in politics, constitutional, legal, and justice. ${ }^{17}$

The mission of the prophet Muhammad in carrying out the values of justice in the Medina Charter article 2 stated that the Muslims must be fair in paying the fine for murdering someone (diyat) and redeeming prisoners so that no party is harmed. Article 13 states that Muslims should be fair in opposing the perpetrators of crime, injustice, and sin. Article 17 states that the non-Muslim groups, Jews, and their allies receive equal protection and equality as Muslims. ${ }^{18}$ Living together tolerantly is the result of the hard work of previous religious figures to build a possibility to develop a more tolerant and open community. ${ }^{19}$

${ }^{13}$ Ahmad Chaerun Ulum, “Eksistensi Dakwah Dalam Merespon Pluralisme," Jurnal Komunida 7, no. 2 (2017), 124.

${ }^{14}$ G.E. Von Grunebaum, Classical Islam (Chicago: Aldine Publishing Company, 1970), 26.

${ }^{15}$ Muhammad Zafrullah Khan, Muhammad Seal of the Prophet (Lahore: Routledge and Kegan paul, 1980), 88

${ }^{16}$ Muhammad Isya Ayash, Social Contrac and Islamic State (New York: Oxford University, 1964), 173.

17 Candra Prabawati, "Penegakan Hak Azasi Manusia Di Era Globalisasi Dalam Perspektif Hukum Islam,” Jurnal Hukum Islam Al- 'Adalah 12, no. 4 (2015): 845.

${ }^{18}$ M. Nasor, Komunikasi Persuasif Nabi Dalam Pembangunan Masyarakat Madani (Surabaya: Penerbit Pustaka Mas, 2011), 233.

${ }_{19}$ Abdul Raouf, "Islam Pluralis dan Multikultural: Memperkokoh Kesatuan Bangsa," Bimas Islam 11, no. 4 (2018): 785. 
Justice is the basic right of every human being, both Muslim and non-Muslim, in order to obtain protection in living together. Justice must be upheld because it becomes the main aspect that requires its citizens to do justice in completing their lives together. Enforcing justice means holding, upholding, and fulfilling a mandate of fulfilling the rights of others. The prophet Muhammad built the aspects of life concerning ethics, morality, rights, and obligations, and blending with the community. Guidance should provide opportunities in various activities to groups to carry out communication and interactions that have psychological bonds with each other. The way of communication should be the communication that can touch the psychological nature of multi-cultural people so that they can establish relationships and achieve the win-win solutions and not the win-lose condition. It means that our partners are not harmed and can get justice. ${ }^{20}$

\section{c. The community that Upholds Noble Characters (Akhlaqul Karimah)}

Guidance on pluralistic life knows no boundaries between the diversity of human life. The diversity of beliefs, customs, and others should be respected as well as to forbid fighting among the members of the community. The existing guidance is also directed at upholding the moral virtues to create unity, peace, and mutual respect in order for the tolerance to rise. Imam Al Gazali says that the formation of moral character shapes the Islamic soul, strives hard, and truly upholds personality. ${ }^{21}$ Syaiful tells us that the awareness of the religious community is the main key for the continuity of harmony and carrying out their respective religions. ${ }^{22}$ People want to live together with other people when there is awareness of the treatment or good morals towards fellow human beings regarding all things.

Brotherhood in people's lives is the principle of the formation of ukhuwah (brotherhood) and solidarity which does not look at ethnicity or culture must be based on aklaqul karimah (noble characters). For the brotherhood to eliminate conflicts, build a community full of love, and help to realize public welfare must be based on noble characters (aklaqul karimah). The existence of brotherhood is an element that must be developed so that it becomes a good personality or character in life. Humans will be trustworthy, have good manners, and willing to defend the truth provided that there is brotherhood based on aklaqul karimah. A strong formation of brotherhood is based on the noble characters that bound the Muhajirin and Ansar, who have different tribes and customs, and other differences. ${ }^{23}$

\section{Conclusion}

A pluralistic community is a community that accepts and respects differences. The community itself is the result of a persuasive communication approach, namely a community that is full of love, mutual respect for diversity, accepting diversity, and building harmony in shared life by paying attention to psychological aspects.

The application of persuasive communication in the pluralistic community based on the Islamic perspective is to guide the community to uphold the faith, the law, and the akhlaqul karimah (noble characters). Such a community will prioritize equality, freedom, justice, and

\footnotetext{
${ }^{20}$ Dedy Mulyana, Komunikasi Antar Budaya: Panduan Berkomunikasi Dengan Orang-Orang Berbeda Budaya (Bandung: Remaja Kerya, 1996), 31.

${ }^{21}$ Imam Al-Ghazali, Ihya' Ulum al-Din (Bairut: Dar al-Fikr, n.d.), 90.

${ }^{22}$ M. Syaeful Rahman, "Islam Dan Pluralisme," Jurnal Firkah 2, no. 2 (2014): 404

${ }^{23}$ Ibnu Hisyam, Sirah Nabawiyah, 2nd ed. (Kairo: Mustafa al-Baby al-Halaby, 1965), 190.
} 
cooperation to achieve prosperity. The success cannot be separated from the existence of a foundation to live together in accordance with the rules or agreements that have been determined. This all creates a tolerant, just, and harmonious pluralistic community as well as a community that upholds brotherhood, unity, and free from discrimination.

\section{References}

[1]. Abdul Raouf. "Islam Pluralis dan Multikultural: Memperkokoh Kesatuan Bangsa." Bimas Islam 11, no. 4 (2018).

[2]. Agama, Departemen. Al-Qura'an Dan Terjemahnya. Jakarta: Yayasan Penterjemah/Penafsir AlQur'an, 1971.

[3]. Ahmad, Zainal Abidin. Piagam Nabi Muhammad SAW Konstitusi Tertulis Pertama Di Dunia. Jakarta: Bulan Bintang, 1973.

[4]. Ahsan, Abdullah al-. Ummah or Nation?, Identity Crisis in Contemporary Muslim Society. The Islamic Fondation, 1992.

[5]. Ali, Maulavi Muhammad. Muhammad The Prophet. Lahore: Iradahi al-Adabiyati, 1950.

[6]. Arnold, Thomas W. The Preaching of Islam. Jakarta: Wijaya, 1985.

[7]. Ayash, Muhammad Isya. Social Contrac and Islamic State. New York: Oxford University, 1964.

[8]. Baso, Ahmad. Civil Society Versus Masyarakat Madani. Bandung: Pustaka Hidayah, 1999.

[9]. Grunebaum, G.E. Von. Classical Islam. Chicago: Aldine Publishing Company, 1970.

[10]. Ibnu Hisyam. Sirah Nabawiyah. 2nd ed. Kairo: Mustafa al-Baby al-Halaby, 1965.

[11]. Imam Al-Ghazali. Ihya' Ulum al-Din. Bairut: Dar al-Fikr, n.d.

[12]. Khan, Muhammad Zafrullah. Muhammad Seal of the Prophet. Lahore: Routledge and Kegan paul, 1980.

[13]. Larson, Charles U. Persuasion, Reception, and Responsibility. USA: Wadsworth Publishing Company, 1986.

[14]. M. Nasor. Komunikasi Persuasif Nabi Dalam Pembangunan Masyarakat Madani. Surabaya: Penerbit Pustaka Mas, 2011.

[15]. Mulyana, Dedy. Komunikasi Antar Budaya: Panduan Berkomunikasi Dengan Orang-Orang Berbeda Budaya. Bandung: Remaja Kerya, 1996.

[16]. Nasir, Sayyid Mahmud al-. Islam Konsepsi Dan Sejarahnya. Bandung: PT. Remaja Karya Rosda Karya, 1994.

[17]. Nasor, M. Kontribusi Komunikasi Dalam Perencanaan Dan Kebijakan Sosial. Bandar Lampung: Universitas Lampung Press, 2012.

[18]. Prabawati, Candra. "Penegakan Hak Azasi Manusia Di Era Globalisasi Dalam Perspektif Hukum Islam.” Jurnal Hukum Islam Al- 'Adalah 12, no. 4 (2015).

[19]. Qardhawi, Yusuf. Al-Sunnah Mashdaran Li al-Ma'rifah Wa al-Hadharah. Cairo: Dar al-Syuruq, 1977.

[20]. Rahman, M. Syaeful. “Islam Dan Pluralisme.” Jurnal Firkah 2, no. 2 (2014).

[21]. Sumardi, Dedy. "Islam Pluralisme Hukum Dan Refleksi Masyarakat Homogen." Jurnal AsySyir'ah 50, no. 2 (2016)

[22]. Ulum, Ahmad Chaerun. "Eksistensi Dakwah Dalam Merespon Pluralisme." Jurnal Komunida 7 , no. 2 (2017). 